\title{
XXVIth Chugaev Conference on Coordination Chemistry Kazan (Russia), October 6-10, 2014
}

Chugaev Conference on Coordination Chemistry is held in different regions of Russia every two years. It is the largest in CIS countries scientific forum covering both fundamental and applied aspects of modern coordination chemistry. One of its major tasks is to strengthen the role of fundamental research in solving practical problems. The Conference has a high international reputation.

XXVIth Chugaev Conference will be held in Kazan, Russia from Monday 6th - Friday 10th October 2014.

The Conference is devoted to the 170th anniversary of the ruthenium discovery by Kazan University professor Karl Klaus. Klaus named the element after Ruthenia, the Latin word for Rus'. It is the only natural element of the periodic system, opened in Russia. The Conference is also dedicated to the 210th anniversary of the Kazan University, where world-famous Kazan chemical school was formed and developed, and to the 80th anniversary of the Institute of General and Inorganic Chemistry of Kurnakov, Moscow.

The conference program includes reports of leading scientists, oral communication on actual problem of coordination chemistry, huge poster sessions, and a school for young scientist. Roundtables on the most important and promising projects in the field of coordination and organometallic chemistry are also planned during the Conference.

\section{International Advisory Committee}

$\begin{array}{ll}\text { Nobel Prize Winner Prof. Jean-Marie Lehn (Strasbourg, France) } & \text { Prof. Wais Hosseini (Strasbourg, France) } \\ \text { Prof. A. I. Konovalov (Kazan) } & \text { Prof. G. L. Kamalov (Ukraine, Odessa) } \\ \text { Nobel Prize Winner Prof. Ryoji Noyori (Nagoya, Japan) } & \text { Prof. V. V. Pavlichyuk (Ukraine, Kiev) } \\ \text { Prof. M. Belinsky (Tel-Aviv, Israel) } & \text { Prof. V. I. Pekhnyo (Ukraine, Kiev) } \\ \text { Prof. O. N. Chupakhin (Ekaterinburg) } & \text { Prof. G. V. Tsintsadze (Tbilisi, Georgia) } \\ \text { Prof. A. P. Gulya (Chisinau) } & \text { Prof. S. V. Volkov (Ukraine, Kiev) } \\ \text { Prof. Dr. Evamarie Hey-Hawkins (Leipzig, Germany) } & \text { Prof. Yu. A. Zolotov (Moscow) }\end{array}$

\section{Organizing Committee}

\section{President of the Conference Co-chairmen of the organizing committee}

Scientific secretary

Prof. G. A. Abakumov (N. Novgorod) Prof. S. M. Aldoshin (Chernogolovka) Prof. I. S. Antipin (Kazan) Prof. V. K. Belsky (Moscow) Prof. V. N. Charushin (Ekaterinburg) Prof. M. P. Egorov (Moscow) Prof. I. L. Eremenko (Moscow) Prof. V. T. Kalinnikov (Moscow) Prof. O. I. Koifman (Ivanovo)
Prof. A. Yu. Tsivadze (Moscow)

Prof. I. R. Gafurov (Kazan)

Prof. V. M. Novotortsev (Moscow)

Prof. O. G. Sinyashin (Kazan)

Prof. V. I. Galkin (Kazan)

Prof. K. Y. Zhizhin (Moscow)

\author{
Prof. N. T. Kuznetsov (Moscow) \\ Prof. V. U. Kukushkin (St. Petersburg) \\ Prof. A. M. Mazgarov (Kazan) \\ The mayor of Kazan I. R. Metshin \\ Prof. V. I. Minkin (Rostov-on-Don) \\ Prof. I. I. Moiseev (Moscow) \\ Prof. V. I. Ovcharenko (Novosibirsk) \\ Prof. R. Z. Sagdeev (Novosibirsk) \\ Minister of Science and Education \\ of the Republic of Tatarstan E. N. Fattakhov
}

The Conference program will include Plenary Lectures, Short Lectures and Poster Presentations. Special session with the short oral presentations of young scientists is planned. English is the official Symposium language. No translation will be provided.

\section{Scientific Program:}

Theoretical aspects of coordination chemistry; Structure and properties of coordination compounds; Methods of coordination compounds synthesis; Mechanisms and intermediates of complex formation;
Ligand reaction in the inner sphere of metal complexes; Metal-complex catalysis; Bio-inorganic chemistry of coordination compounds; Practical applications of coordination compounds.

Contact: For further information on Chugaev Conference please contact: Angelika Karasik, A. E. Arbuzov Institute of Organic and Physical Chemistry, Arbuzov str., 8, Kazan, Russia. Email: a_karasik@iopc.ru 